\title{
OPTIMALISASI PENGELOLAAN DANA ALOKASI KHUSUS (DAK) UNTUK MENDORONG PERTUMBUHAN PEMBANGUNAN DAERAH DI INDONESIA
}

\author{
Agus Sunarya Sulaeman \\ Politeknik Keuangan Negara STAN \\ asunarya@pknstan.ac.id \\ Novi Andriyanto \\ Politeknik Keuangan Negara STAN \\ andriyanto.novi@gmail.com
}

\section{Article History:}

Received: 22 Januari 2021

Revised: 26 April 2021

Accepted: 26 April 2021
Abstract : Fiscal decentralization in Indonesia lately continues to increase in terms of the amount of funds. One of the transfers to the regional government is the Specific-Purpose Grants (DAK), in addition to the Revenue-Sharing Grant (DBH) and the General-Purpose Grants (DAU). The purpose of fiscal decentralization is to encourage equity and growth in regional development. This study aims to examine the impact of detailed DAK in various fields on the growth of regional development. The data analysis of this study used Human Development Indexs to measure development growth, and used panel data regression from the realization of district / city DAK per sector in Indonesia, plus economic growth factors, financial statement opinions, types of local governments and regional locations. The results of the analysis indicate that the impact of most DAK for Small and Medium Industry, Health and Family Planning and Transportation have a positive effect, and DAK in the field of Marine and Fisheries, Education, Housing, Water and Sanitation have a negative effect, and DAK in the Agriculture sector has no effect. From this research, policy makers can look for steps to optimize the distribution and use of DAK in the context of fiscal decentralization.

Abstrak: Desentralisasi fiskal di Indonesia akhirakhir ini terus meningkat dari segi jumlah dananya. Salah satunya melalui transfer Dana Alokasi Khusus (DAK), selain Dana Bagi Hasil (DBH) dan Dana Alokasi Umum (DAU). Tujuan transfer ke daerah adalah untuk mendorong pemerataan dan pertumbuhan pembangunan di daerah. Penelitian ini bertujuan menguji dampak DAK yang terinci dalam berbagai bidang terhadap pertumbuhan 


\begin{tabular}{|l|l|}
\hline & $\begin{array}{l}\text { Pembangunan daerah. Analisis data penelitian ini } \\
\text { menggunakan Indeks Pembangunan Manusia untuk } \\
\text { mengukur pertumbuhan pembangunan, dan } \\
\text { menggunakan regresi data panel dari realisasi DAK } \\
\text { kabupaten/kota per bidang se Indonesia, ditambah } \\
\text { faktor pertumbuhan ekonomi, opini laporan } \\
\text { keuangan, jenis pemerintah daerah dan lokasi } \\
\text { daerah. Hasil analisis mengindikasikan bahwa } \\
\text { dampak DAK bidang Industri Kecil Menengah, } \\
\text { Kesehatan dan KB serta Transportasi berpengaruh } \\
\text { positif, dan DAK bidang Kelautan dan Perikanan, } \\
\text { Pendidikan, Perumahan Air Minum Sanitasi } \\
\text { berpengaruh negatif, dan DAK bidang Pertanian } \\
\text { tidak berpengaruh. Dari Penelitian ini pengambil } \\
\text { kebijakan dapat mencari langkah optimalisasi } \\
\text { penyaluran dan penggunaan DAK dalam rangka } \\
\text { desentrasisasi fiskal. }\end{array}$ \\
\hline Keywords: Specific- Purpose Grants, Human Development Index, \\
transfers, decentralization kunci: Dana Alokasi Khusus, Indeks Pembangunan Manusia, \\
transfer, desentralisasi
\end{tabular}

\section{PENDAHULUAN}

Rencana Pembangunan Jangka Menengah Nasional (RPJMN) Pemerintah Tahun 2014-2019 menyebutkan bahwa pembangunan nasional harus diwujudkan dengan pemerataan pembangunan yang dengan meningkatkan pembangunan daerah, mengurangi kesenjangan sosial secara menyeluruh, menanggulangi kemiskinan dan pengangguran dan menyediakan akses yang sama bagi masyarakat terhadap berbagai pelayanan sosial serta sarana dan prasarana ekonomi. Salah satu indikator kinerja pembangunan yang kerap digunakan untuk menjadi tolok ukur keberhasilan pembangunan di suatu negara menurut Pasaribu (Pasaribu 2005) adalah Indeks Pembangunan Manusia (IPM). IPM memiliki keunggulan dibanding indikator pembangunan lain karena dapat menggambarkan dimensi yang lebih lengkap di mana menggabungkan indikator di sektor pendidikan, kesehatan dan juga perekonomian.

Selama kurun waktu 3 tahun terakhir, tingkat pembangunan manusia Indonesia dalam lingkup ASEAN berada pada urutan ke-6, di bawah Singapura, Brunei, Malaysia, Thailand dan Filipina. Pada tahun 2016, untuk peringkat secara dunia, Indonesia juga turun ke peringkat 113 dari sebelumnya pada peringkat 110 . Pembangunan manusia di Indonesia juga masih menyisakan beberapa persoalan terutama ketimpangan dimana kemajuan IPM di Indonesia belum memberi manfaat bagi semua orang karena adanya kesenjangan yang berdampak negatif pada kelompok tertentu secara tidak proporsional (United Nations 
Development Programme, 2016). Hal ini menunjukkan perlu adanya langkah-langkah perbaikan kebijakan publik oleh pemerintah dalam meningkatkan kesejahteraan masyarakat agar tidak semakin tertinggal dari negara lain.

Di tengah kondisi pembangunan manusia yang belum memuaskan tersebut, pemerintah melaksanakan kebijakan desentralisasi fiskal yang ditujukan untuk meningkatkan kapasitas keuangan daerah melalui pemberian transfer ke daerah secara berkelanjutan. Pemberian transfer ke daerah pada dasarnya merupakan upaya pemerintah pusat dalam rangka mewujudkan penyediaan pelayanan dasar bagi masyarakat (Sulaeman and Silvia 2019). Tren perkembangan alokasi transfer ke daerah setiap tahunnya juga terus meningkat bahkan nilainya cukup signifikan bila dilihat dari proporsinya terhadap belanja APBN secara keseluruhan. Desentralisasi fiskal dapat mendorong efisiensi ekonomi dan secara dinamis akan mendorong pertumbuhan ekonomi suatu daerah karena pemerintah daerah lebih mengetahui karateristik daerahnya masingmasing sehingga pengalokasian anggaran untuk pembangunan dapat lebih efisien daripada jika dilakukan oleh pemerintah pusat (Lewis 2017).

Dari berbagai jenis dana transfer ke daerah, salah satu jenis dana yang berbentuk specific-purpose grant adalah Dana Alokasi Khusus (DAK). Adapun jika dilihat dari besaran nilainya, Dana Alokasi Khusus (DAK) memang tidak sebesar komponen dana transfer yang lain. Hal ini dapat kita lihat dari tren 3 tahun terakhir di mana proporsi DAK secara total terhadap anggaran transfer ke daerah hanya berkisar antara 8 s.d. $12 \%$. Jenis transfer ke daerah yang bernilai besar masih didominasi oleh general-purpose grant berupa DAU dan DBH.

Meskipun nilainya kecil, DAK memiliki peran strategis dalam upaya pembangunan sarana dan prasarana pelayanan dasar di daerah karena sifatnya yang mengharuskan penggunaan dana tersebut untuk kegiatan yang telah ditentukan oleh pemerintah pusat. Pemerintah pusat dapat memastikan bahwa DAK yang disalurkan akan digunakan oleh daerah untuk mendanai kegiatan pelayanan dasar masyarakat yang penting seperti pendidikan, kesehatan, maupun infrastruktur. Dengan demikian, diharapkan DAK dapat memberikan pengaruh/dampak yang lebih efektif dibandingkan jenis dana transfer lainnya.

Besarnya harapan terhadap outcome yang dihasilkan oleh DAK masih terkendala oleh beberapa permasalahan, isu, dan tantangan dalam tata kelola DAK di Indonesia (Bappenas, 2011, 119-122). Atas permasalahan yang diidentifikasi, pemerintah melalui berbagai kementerian terkait seperti Kementerian Keuangan, Bappenas, Kemendagri, maupun kementerian teknis lainnya terus berupaya melakukan perbaikan tata kelola DAK mulai dari proses perencanaan, penganggaran, pelaksanaan hingga pemantauan dan evaluasi (Nota Keuangan APBN Tahun 2017-2018). Perubahan yang paling signifikan 
antara lain adalah adanya perubahan paradigma perencanaan DAK yang sebelumnya berbasis input menjadi berbasis output, perubahan kriteria daerah penerima DAK yang diubah menjadi bersifat bottom-up melalui mekanisme proposal dan sinkronisasi perencanaan pembangunan antartingkat pemerintah dan antardaerah.

Berbagai permasalahan dalam tata kelola DAK sebagaimana telah disebutkan di atas, menjadikan pertanyaan dalam penelitian ini bagaimana optimalisasi DAK memberikan dampak yang optimal terhadap indikator kinerja pembangunan. Beberapa penelitian yang telah dilakukan dalam mengaitkan pengaruh DAK terhadap IPM menunjukkan hasil yang beragam, yaitu terdapat simpulan berupa berpengaruh positif signifikan (Fadhly, 2017), signifikan namun negatif (Purba, 2016) dan tidak berpengaruh (Sarkoro dan Zulfikar, 2016).

Sebagian besar penelitian yang membahas pengaruh DAK terhadap IPM menggunakan variabel DAK secara total, sedangkan penelitian berdasarkan bidang DAK masih sangat sedikit. Hal ini membuat rujukan evaluasi dan analisis atas kinerja bidang-bidang yang ada di dalam DAK belum cukup banyak ditemukan. Perubahan dalam tata kelola DAK yang telah dilakukan juga belum banyak dievaluasi apakah memang dapat memperbaiki pencapaian outcome dari DAK berupa peningkatan kualitas hidup masyarakat di daerah. Oleh karena itu, pada penelitian ini akan dilakukan analisis terkait bagaimana pengaruh realisasi DAK per bidang terhadap indikator kinerja pembangunan berupa Indeks Pembangunan Manusia (IPM) kabupaten/kota di Indonesia dalam beberapa tahun terakhir.

Penelitian ini menganalisis bagaimana transfer ke daerah untuk Dana Alokasi Khusus bisa meningkatkan Indek Pembangunan Manusia. Tujuan penelitian ini menganalis dampak DAK dalam berbagai bidang terhadap pengembangan pembangunan manusia di daerah.

\section{LITERATUR REVIEU DAN PENGEMBANGAN HIPOTESIS}

Desentralisasi fiskal merupakan salah satu komponen utama dari desentralisasi. Pemerintah dalam rangka menjalankan fungsinya terkait pemberian layanan sektor publik harus didukung sumber-sumber keuangan yang memadai, di mana salah satunya melalui subsidi/bantuan dari Pemerintah Pusat. Terdapat beberapa pendapat yang mendukung desentralisasi antara lain yang menyebutkan bahwa pelayanan publik yang dilakukan oleh pemerintah akan lebih efisien bila dilaksanakan oleh daerah yang memiliki kontrol geografis lebih kecil ((Sidik 2002);(Sulaeman 2018) ), hal ini dikarenakan:

a. Pemerintah daerah lebih memahami permasalahan dan kebutuhan masyarakatnya.

b. Pemerintah daerah sangat responsif dalam memenuhi kebutuhan masyarakat, sehingga pemerintah lokal terdorong untuk lebih efisien dalam mengelola dana yang dihimpun dari masyarakat.

c. Pemerintah daerah terus berinovasi karena adanya persaingan 
antardaerah dalam memberikan pelayanan kepada masyarakat.

Martinez-Vazquez, dkk $(2011,1)$ menyebutkan bahwa dorongan untuk melakukan desentralisasi pada beberapa negara disebabkan karena antara lain kebutuhan untuk mendapat pengelolaan publik yang lebih efisien, ketidakpuasan atas kinerja kebijakan publik yang terpusat, serta adanya tanda-tanda gerakan separatisme sehingga diperlukan kebijakan untuk mengurangi tekanan politik lokal (Martinez-Vazquez and McNab 2005).

Bila merujuk pada beberapa literatur keuangan negara, bentuk dana transfer dapat dikategorikan menjadi dua, yaitu general-purpose grant dan specific-purpose grant (Suwandi and Warokka 2013). Bila dilihat dari karakteristiknya, DAK merupakan jenis transfer ke daerah yang termasuk ke dalam specific matching closed-ended grant (Bappenas, $2011,65)$. Selain itu bila melihat persyaratan penggunaannya yang hanya digunakan untuk pembangunan infrastruktur fisik, maka DAK (Fisik) dapat juga dikategorikan sebagai capital grant.

Specific-purpose grant lebih tepat diterapkan dalam keadaan akuntabilitas pemerintah daerah masih rendah dan ketika fokus pemerintah pusat adalah mendorong pencapaian prioritas nasional terkait dengan standar pelayanan dasar. Pemerintah pusat sebagai pemberi dana dapat memastikan bahwa dana yang mereka salurkan digunakan pada aktivitas/bidang tertentu yang telah mereka tentukan (Wardhana et al. 2013). Pelayanan publik seperti pelayanan kesehatan dan pendidikan sangat penting dalam pembangunan modal manusia (Juanda and Handra 2017). Adanya standar minimal atas pelayanan publik tersebut memperbaiki pergerakan barang modal dan tenaga kerja antardaerah yang dapat meningkatkan efisiensi perekonomian. Peningkatan modal manusia sangat penting dalam memacu pertumbuhan ekonomi dan peningkatan pendapatan per kapita masyarakat (Petchey dan Macdonald, 2007, 447)

Machfud Sidiq $(2003,14)$ mengatakan bahwa pada hakikatnya pengertian Dana Alokasi Khusus (DAK) adalah dana yang berasal dari APBN, yang dialokasikan kepada Daerah untuk membantu membiayai kebutuhan khusus. Pengalokasian DAK ditentukan dengan memperhatikan tersedianya dana dalam APBN. Definisi tersebut selaras dengan UndangUndang No. 33 Tahun 2004 tentang Perimbangan Keuangan antara Pemerintah Pusat dengan Pemerintahan Daerah yang menyebutkan bahwa Dana Alokasi Khusus, selanjutnya disebut DAK, adalah dana yang bersumber dari pendapatan APBN yang dialokasikan kepada Daerah tertentu dengan tujuan untuk membantu mendanai kegiatan khusus yang merupakan urusan Daerah dan sesuai dengan prioritas nasional. Secara umum, kebijakan pemberian Dana Alokasi Khusus bertujuan untuk :

a. mendanai kegiatan penyediaan sarana dan prasarana fisik pelayanan dasar. 
b. Mendorong peningkatan produktivitas perluasan kesempatan kerja dan diversifikasi ekonomi.

c. Meningkatkan akses penduduk miskin terhadap pelayanan dasar dan prasarana dasar.

d. Menjaga dan meningkatkan kualitas hidup, serta mencegah kerusakan lingkungan hidup, dan mengurangi risiko bencana.

Bidang dalam DAK setiap tahunnya terus berkembang. Adapun berdasarkan Peraturan Presiden Republik Indonesia Nomor 123 Tahun 2016 tentang Petunjuk Teknis Dana Alokasi Khusus Fisik, bidang dalam DAK Fisik meliputi Pendidikan, Kesehatan, Perumahan dan Pemukiman, Pertanian, Kelautan dan Perikanan, Air Minum, Sanitasi, Jalan, Irigasi, Transportasi, dan Sentra Industri Kecil Menengah.

IPM merupakan gabungan dari pengukuran rata-rata pencapaian dalam beberapa dimensi kunci terkait pembangunan manusia, yaitu: Kesehatan; Pengetahuan/Pendidikan; dan Standar hidup layak.

IPM menurut BPS juga menjadi tolok ukur bagaimana penduduk dapat mengakses hasil pembangunan dalam memperoleh pendapatan, kesehatan dan pendidikan. IPM memiliki manfaat sebagai berikut:

a. IPM merupakan indikator penting untuk mengukur keberhasilan dalam upaya membangun kualitas hidup manusia (masyarakat/penduduk).

b. IPM dapat menentukan peringkat atau level pembangunan suatu wilayah/negara.

c. Bagi Indonesia, IPM merupakan data strategis karena selain sebagai ukuran kinerja Pemerintah, IPM juga digunakan sebagai salah satu alokator penentuan Dana Alokasi Umum (DAU).

DAK Bidang Kesehatan berpengaruh signifikan dan positif terhadap IPM, DAK Bidang Lingkungan Hidup dan DAK Bidang Pendidikan tidak berpengaruh terhadap IPM (Bappenas (2011) Analisis Perspektif, Permasalahan dan Dampak Dana Alokasi Khusus (Zul Fadhly 2013). Pendapat lain tentang pengaruh negatif DAK terhadap Indeks Pembangunan Manusia dikemukan oleh (Purba, 2017). Penlitian nya dilakukan dengan menggunakan intermedias Belanja Modal dan Pertumbuhan Ekonomi. Iokusnya pada Kabupaten/Kota Di Propinsi Sumatera Utara. Fadhly (2017) mengungkapkan ada Pengaruh Pendapatan Asli Daerah, Dana Alokasi Umum dan Dana Alokasi Khusus terhadap Indeks Pembangunan Manusia di Provinsi Sumatera Barat (DAK berpengaruh secara signifikan dan positif terhadap IPM. Sementara itu, Sarkoro \& Zulfikar (2016) menyatakan Dana Alokasi Khusus dan Pendapatan Asli Daerah terhadap Indeks Pembangunan Manusia (DAK tidak berpengaruh terhadap IPM)

Berdasarkan landasan teori dan hasil dari penelitian sebelumnya, maka diusulkan hipotesis sebagai berikut:

$H_{1}=$ DAK Bidang Sentra Industri Kecil Menengah memiliki pengaruh positif dan signifikan terhadap Pertumbuhan Pembangunan Daerah. 
$H_{2}=$ DAK Bidang Pertanian memiliki pengaruh positif dan signifikan terhadap Pertumbuhan pembangunan daerah

$H_{3}$ = DAK Bidang Kesehatan dan KB memiliki pengaruh positif dan signifikan terhadap Pertumbuhan Pembangunan Daerah

$H_{4}=$ DAK Bidang Kelautan dan Perikanan memiliki pengaruh positif dan signifikan terhadap Pertumbuhan Pembangunan Daerah

$H_{5}=$ DAK Bidang Pendidikan memiliki pengaruh positif dan signifikan terhadap Pertumbuhan Pembangunan Daerah

$H_{6}=$ DAK Bidang Perumahan, Air Minum dan Sanitasi memiliki pengaruh positif dan signifikan terhadap Pertumbuhan Pembangunan Daerah

$H$ = DAK Bidang Transportasi memiliki pengaruh positif dan signifikan terhadap Pertumbuhan Pembangunan Daerah

\section{METODOLOGI PENELITIAN}

Penelitian ini berupa penelitian penjelasan (explanatory research) yaitu penelitian dengan melihat hubungan antarvariabel dan menguji hipotesis yang telah dirumuskan sebelumnya, sedangkan jenis data yang digunakan adalah data sekunder. Data sekunder dalam penelitian ini akan didapat dari beberapa sumber, antara lain Kementerian Keuangan, Badan Pusat Statistik (BPS), Badan Pemeriksa Keuangan (BPK), lembagalembaga penelitian lain, dan/atau perguruan tinggi lain. Penelitian ini akan menggunakan data panel yaitu data gabungan dari data cross section dan time series. Data cross section dalam penelitian ini adalah daerah penerima DAK yaitu kabupaten/kota dengan time series selama 3 tahun dari tahun 2016 s.d. 2018.

Variabel independen yang digunakan adalah nilai realisasi DAK per bidang dan beberapa variabel faktor lainnya. Variabel DAK per bidang untuk setiap kabupaten/kota terdiri dari bidang sentra industri kecil menengah, pertanian, kesehatan dan KB, kelautan-perikanan, pendidikan, perumahan air minum sanitasi, dan transportasi. Sedangkan untuk variabel faktor lainnya termasuk Produk Domestik Bruto Regional (PDRB) kabupaten/kota, pertumbuhan ekonomi, opini laporan keuangan, jenis pemerintah daerah dan lokasi daerah.

Nilai realisasi bidang DAK menggunakan satuan miliar rupiah. PDRB menggunakan satuan triliun rupiah sedangkan pertumbuhan ekonomi menggunakan satuan persen. Variabel opini laporan keuangan menggunakan data dummy yaitu jika suatu daerah selama 3 tahun kurun waktu data penelitian mendapatkan opini WTP atau WDP maka akan mendapatkan angka 1. Namun jika daerah tersebut pernah mendapatkan opini selain WTP dan WDP (Tidak Menyatakan Pendapat atau Tidak Wajar), maka akan mendapat nilai 0 . Jenis pemerintah daerah juga menggunakan data dummy yaitu jika jenis pemerintahan daerahnya kota maka mendapat nilai 1 , sedangkan jika jenis pemerintahannya kabupaten maka akan mendapat nilai 0 . Untuk lokasi daerah, maka dipisahkan 
dengan variabel dummy di mana untuk daerah di Pulau Jawa akan mendapat nilai 1 , sedangkan untuk daerah di luar Pulau Jawa akan mendapat nilai 0 .

Variabel dependen yang digunakan adalah Indeks Pembangunan Manusia (IPM). IPM merupakan gabungan dari pengukuran rata-rata pencapaian dalam beberapa dimensi kunci terkait pembangunan manusia, yaitu kesehatan, pengetahuan/ pendidikan dan standar hidup layak. IPM dihitung sebagai rata-rata geometrik dari indeks kesehatan, pendidikan, dan pengeluaran. Ketiga indeks ini direpresentasikan melalui angka harapan lama sekolah, angka rata-rata lama sekolah, angka harapan hidup dan pengeluaran per kapita yang disesuaikan.

Untuk melihat pengaruh dari nilai realisasi DAK terhadap indeks pembangunan manusia, maka penelitian ini akan menggunakan analisis model regresi data panel dengan interaksi di setiap kabupaten/kota untuk tahun 2016 s.d. 2018 dengan sampel daerah kabupaten/kota yang menerima DAK dan bidang DAK yang secara konsisten disalurkan selama 3 tahun berturut dalam masa penelitian. Untuk mengetahui hubungan antara variabel independen (DAK per bidang) terhadap variabel dependen (IPM) maka digunakan model regresi linear berganda sebagai berikut:

$$
\begin{aligned}
I P M_{i, t}= & a+B_{1} D A K I K M_{(i, t-1)+B_{2} D A K P R T_{(i, t-1)}+B_{3} D A K K K B_{(i, t-1)}+} \\
& B_{4} D A K K L P_{(i, t-1)}+B_{5} D A K P D K_{(i, t-1)}+B_{6} D A K P M S_{(i, t-1)}+ \\
& B_{7} D A K T R P_{(i, t-1)}+B_{8} P D R B_{(i, t)}+B_{10} P E_{(i, t)}+B_{9} O L K_{(i, t)}+ \\
& B_{11} \operatorname{LoKD}_{(i, t)}+B_{12} \operatorname{JenPDD}_{(i, t)+\varepsilon}
\end{aligned}
$$

Keterangan:

$$
\begin{array}{ll}
\text { IPM } & =\text { Indeks Pembangunan Manusia } \\
a & =\text { Konstanta } \\
\text { B } & =\text { Koefisien regresi } \\
\text { DAKIKM } & =\text { DAK Bidang Industri Kecil Menengah } \\
\text { DAKPRT } & =\text { DAK Bidang Pertanian } \\
\text { DAKKKB } & =\text { DAK Bidang Kesehatan dan KB } \\
\text { DAKKLP } & =\text { DAK Bidang Kelautan dan Perikanan } \\
\text { DAKPDK } & =\text { DAK Bidang Pendidikan } \\
\text { DAKPMS } & =\text { DAK Bidang Perumahan Air Minum Sanitasi } \\
\text { DAKTRP } & =\text { DAK Bidang Transportasi } \\
\text { PDRB } & =\text { Produk Domestik Regional Bruto } \\
\text { PE } & =\text { Pertumbuhan Ekonomi } \\
\text { OLK } & =\text { Dummy opini laporan keuangan pemerintah daerah } \\
\text { LokasiD } & =\text { Dummy lokasi daerah (Jawa/luar Jawa) } \\
\text { JenisPD } & =\text { Dummy jenis pemerintahan daerah (kota/kabupaten) } \\
\mathrm{i} & =\text { kota/kabupaten ke-i } \\
t & =\text { tahun ke-t }
\end{array}
$$

Penelitian ini menggunakan metode lag di mana analisis regresi dilakukan tidak secara langsung pada tahun yang sama namun dengan periode yang berbeda. Penggunaan lag akan diterapkan pada variabel 
realisasi DAK per bidang dimana akan menggunakan data $\mathrm{t}-1$. Metode lag digunakan untuk menyempurnakan penelitian yang sebelumnya dilakukan oleh Bappenas (2011) yang baru menggunakan analisis data untuk periode yang sama. Pada penelitian tersebut dijelaskan bahwa pengaruh dari DAK terhadap indikator kinerja pembangunan belum terlihat optimal mungkin dikarenakan efek yang dihasilkan dari realisasi DAK baru akan terlihat dalam jangka panjang.

Kerangka Konsep Penelitian dalam pembahasan penelitian membagi dana alokasi khusus dalam tujuh bidang

Gambar 2. Kerangka Konsep Penelitian

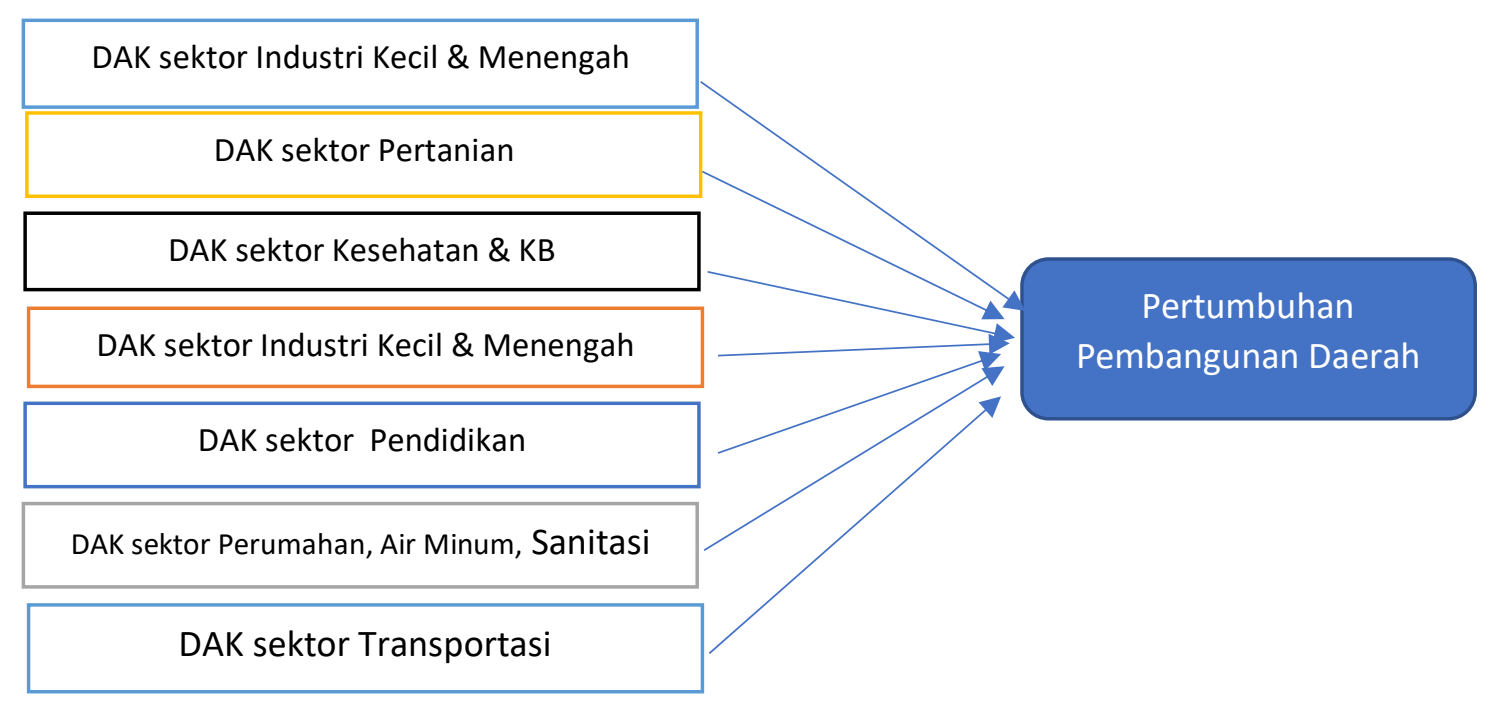

\section{HASIL PENELITIAN DAN PEMBAHASAN}

\section{Deskriptif Hasil Penelitian}

Ukuran statistik IPM Kabupaten/kota yang digunakan dalam penelitian digambarkan pada tabel 3. Rata-rata, median, nilai maksimum dan nilai minimum variabel IPM setiap tahun yang terus meningkat menunjukkan bahwa secara umum terdapat perbaikan IPM secara konsisten. Selisih rata-rata yang sangat tinggi antara nilai maksimum dan nilai minimum (85,49 dibanding 25,47) menunjukkan bahwa masih terdapat ketimpangan pembangunan manusia yang tinggi antara kabupaten/kota maju dan tertinggal di Indonesia. Standar deviasi yang berkisar di antara nilai 6,6 dan 6,7 menunjukkan bahwa sebaran data IPM secara umum tidak memiliki variasi yang besar namun tetap perlu mendapat perhatian agar pemerataan pembangunan manusia di Indonesia menjadi lebih baik. 
Tabel 3. Ukuran statistik IPM Kabupaten/Kota tahun 2016-2018

\begin{tabular}{|c|c|c|c|c|c|}
\hline Tahun & Mean & Median & Max & Min & Std. Dev \\
\hline $\mathbf{2 0 1 6}$ & 66,95 & 66,87 & 84,56 & 25,47 & 6,78 \\
\hline $\mathbf{2 0 1 7}$ & 67,53 & 67,48 & 85,32 & 26,56 & 6,72 \\
\hline $\mathbf{2 0 1 8}$ & 68,10 & 67,86 & 85,49 & 27,87 & 6,61 \\
\hline $\boldsymbol{A l I}$ & 67,53 & 67,42 & 85,49 & 25,47 & 6,72 \\
\hline
\end{tabular}

Sumber: hasil olah data

Ukuran statistik variabel DAK per bidang ditampilkan pada Tabel 4; Nilai rata-rata variabel DAK untuk setiap bidang per kabupaten/kota adalah berkisar antara 2,35 miliar hingga 27,2 miliar rupiah. Nilai rata-rata tertinggi adalah DAK bidang Kesehatan dan KB, sedangkan yang terendah adalah DAK bidang Sentra Industri Kecil Menengah. Urutan dari rata-rata realisasi DAK per bidang berturut-turut dari tertinggi hingga terendah adalah bidang Kesehatan dan KB, Transportasi, Pendidikan, Pertanian, Perumahan Air Minum Sanitasi, Kelautan dan Perikanan, dan Sentra Industri Kecil Menengah. Besaran dari rata-rata realisasi DAK ini secara tidak langsung menunjukkan bidang mana yang menjadi prioritas pemerintah pusat untuk didanai dengan menggunakan DAK. Selain itu, secara umum bidang di DAK dengan nilai besar adalah bidang yang termasuk ke dalam layanan dasar yang wajib disediakan oleh pemerintah daerah menurut Undang Nomor 23 Tahun 2014 tentang Pemerintahan Daerah

Tabel 4. Ukuran Statistik Variabel DAK per Bidang 2016-2018 (dalam miliar rupiah)

\begin{tabular}{|c|r|r|r|r|r|}
\hline DAK & Mean & Median & \multicolumn{1}{c|}{ Max } & Min & Std. DeV \\
\hline IKM & 2,35 & 1,03 & 37,80 & 0,00 & 3,43 \\
\hline PRT & 10,80 & 5,47 & 166,00 & 0,00 & 15,30 \\
\hline KKB & 27,20 & 17,30 & 189,00 & 0,00 & 27,10 \\
\hline KLP & 3,40 & 1,99 & 30,80 & 0,00 & 3,50 \\
\hline PDK & 17,50 & 9,36 & 149,00 & 0,00 & 19,40 \\
\hline PMS & 5,29 & 4,67 & 54,00 & 0,00 & 4,99 \\
\hline TRP & 25,10 & 4,12 & 336,00 & 0,00 & 45,80 \\
\hline
\end{tabular}

Sumber: hasil olah data

Nilai maksimum dari berbagai bidang DAK menunjukkan selisih yang sangat besar dengan nilai rata-rata dan mediannya. Hal ini menunjukkan bahwa terdapat variasi nilai yang cukup tinggi antara realisasi suatu bidang DAK pada satu daerah dengan daerah lainnya. Seluruh nilai minimum DAK per bidang juga bernilai 0 menunjukkan bahwa tidak semua daerah mendapatkan alokasi DAK untuk setiap bidang. Sebaran data tersebut sesuai dengan karakteristik pengalokasian DAK saat ini yang ditentukan berdasarkan pemenuhan persyaratan teknis dan 


\section{$J A A$}

Vol. 5, No. 2, April 2021

prioritas nasional. Akibatnya, pengalokasian DAK untuk setiap bidang tidak merata ke seluruh daerah namun ditentukan dari penilaian kebutuhan dan kesiapan daerah masing-masing.

Berdasarkan estimasi model dengan random effect model, dan sudah dilakukan pengujian asumsi klasik, maka dihasilkan $F_{\text {hitung }}$ sebesar 79,20552 dan Prob ( $F_{\text {statistic }}$ ) sebesar 0,000000.

Tabel 5. Hasil Estimasi Model Regresi Panel

\begin{tabular}{|c|c|c|c|c|}
\hline Variabel & Koefisien & t-Stat & Prob. & $\mathbf{R}^{2}$ \\
\hline C & 63,834000 & 96,617090 & 0,0000 & \multirow[t]{2}{*}{0,6052} \\
\hline DAKIKM & 0,011052 & 2,324121 & 0,0203 & \\
\hline DAKPRT & 0,000515 & 0,808379 & 0,4191 & \multirow[t]{2}{*}{ Adjusted $\mathrm{R}^{2}$} \\
\hline DAKKKB & 0,002240 & 4,254855 & 0,0000 & \\
\hline DAKKLP & $-0,028931$ & $-6,209045$ & 0,0000 & \multirow[t]{2}{*}{0,600550} \\
\hline DAKPDK & $-0,005042$ & $-6,307340$ & 0,0000 & \\
\hline DAKPMS & $-0,010488$ & $-2,146730$ & 0,0158 & F-Stat \\
\hline DAKTRP & 0,000448 & 1,991108 & 0,0467 & \multirow{2}{*}{128,16} \\
\hline PDRB & 0,032234 & 3,438251 & 0,0006 & \\
\hline PE & $-0,000156$ & $-0,022808$ & 0,9818 & \multirow[t]{2}{*}{ Prob.F } \\
\hline OLK & 2,190499 & 3,206242 & 0,0014 & \\
\hline JenisPD & 1,607350 & 3,865781 & 0,0001 & \multirow[t]{2}{*}{0,0000} \\
\hline LokasiD & 8,217309 & 20,969570 & 0,0000 & \\
\hline
\end{tabular}

Estimasi persamaan regresi di atas dapat direpresentasikan dalam bentuk persamaan di bawah. Prob ( $F_{\text {statistic }}$ ) yang kurang dari 0,05 menunjukkan bahwa variabel-variabel independen dalam model secara bersama-sama memiliki pengaruh yang signifikan terhadap Indeks Pembangunan Manusia kab/kota di Indonesia selama tahun 2015 s.d. 2018.

$$
\begin{aligned}
& \operatorname{IPM}_{(i, t)}=63,8384+0,011052 D A K I K M_{(i, t-1)}+0,000515 D A K P R T_{(i, t-1)}+ \\
& 0,00224 D A K K B_{(i, t-1)}-0,028931 D A K K L P_{(i, t-1)}-0,005042 D A K P D K_{(i,} \\
& t-1)-0,010488 \operatorname{DAKPMS}_{(i, t-1)}+0,000448 \operatorname{DAKTRP}_{(i, t-1)}+ \\
& 0,032234 p d r b_{(i, t)}-0,000156 p e_{(i, t)}+2,190050 k_{(i, t)}+ \\
& 8,217309 \text { JenisPD }(i, t)+1,60735 \text { Lokasi }_{(i, t)+\varepsilon}
\end{aligned}
$$

Nilai koefisien determinasi menunjukkan $R$-squared dan Adjusted $R$ square masing-masing sebesar 0,605272 dan 0,6006. Adjusted $\mathrm{R}^{2}$ pada model di atas yang menunjukkan nilai 0,6006 dapat diinterpretasikan bahwa $60,06 \%$ perubahan/variasi nilai indikator kinerja pembangunan berupa IPM mampu dijelaskan oleh perubahan variabel independen dalam model penelitian, sedangkan sisanya 39,94\% dipengaruhi oleh faktor lainnya.

Untuk mengetahui pengaruh variabel independen secara parsial terhadap variabel dependen dilakukan uji statistik t. Penelitian 
menggunakan tingkat signifikansi $5 \%$ sehingga bila nilai probabilitas ( $p$ value) suatu variabel lebih besar dari $5 \%$ maka variabel tersebut tidak signifikan sehingga $\mathrm{H}_{\mathrm{o}}$ diterima dan $\mathrm{H}_{\mathrm{a}}$ ditolak.

Analisis pengaruh nilai DAK per bidang terhadap indikator kinerja pembangunan berupa Indeks Pembangunan Manusia (IPM) berdasarkan hasil penelitian akan dijelaskan melalui hasil estimasi model yang didapat. Secara umum dampak DAK terhadap IPM memang belum optimal. Dari 7 jenis bidang yang dianalisis pada penelitian ini, hanya 3 yang menunjukkan pengaruh positif dan signifikan, sedangkan bidang yang lain justru tidak berpengaruh atau berpengaruh signifikan namun negatif. Hal ini menandakan bahwa DAK belum secara efektif memberikan dampak positif terhadap kinerja pembangunan yang salah satunya ditunjukkan dengan IPM.

Belum optimalnya dampak yang diberikan oleh DAK bisa diakibatkan karena tata kelola DAK yang belum baik. Salah satu indikatornya adalah masih adanya beberapa permasalahan DAK baik di level perencanaan dan pengalokasian, pelaksanaan maupun monitoring dan evaluasinya (Bappenas, 2011, 119-122). Pada level perencanaan, DAK masih perlu memberikan ruang diskresi dan otonomi yang lebih besar kepada daerah dalam tata kelola DAK. Pada level pelaksanaan, DAK saat ini masih mengejar level spending dan berorientasi input. Sedangkan pada level monitoring dan evaluasi, belum terdapat pelaksanaan evaluasi berbasis output/outcome yang memadai.

\section{Realisasi DAK Bidang Sentra Industri Kecil Menengah (DAKIKM) berpengaruh secara positif dan signifikan terhadap indikator kinerja pembangunan.}

Dilandasi dengan banyaknya potensi daerah yang bisa digunakan untuk penumbuhan IKM dan tersebarnya beberapa IKM yang telah tumbuh maka DAK Bidang IKM ditujukan untuk membiayai pembangunan sentra IKM yang dapat membuat pengembangan dan penumbuhan IKM dapat berjalan secara efisien. Berdasarkan penelitian Taiwo, dkk (2012), faktor yang mendukung keberhasilan industri kecil dan menengah adalah dukungan finansial, tidak adanya korupsi, pengalaman dan pelatihan dan infrastruktur yang baik.

Hasil estimasi yang menunjukkan pengaruh positif menggambarkan bahwa penggunaan DAK Bidang IKM saat ini sudah cukup tepat. Hasil ini juga mengindikasikan bahwa pembangunan sentra IKM dapat memberikan pengaruh positif terhadap IPM terutama komponen pendapatan per kapita disesuaikan. Hasil pengujian ini sesuai dengan penelitian Hadiyanti (2015) yang menunjukkan bahwa investasi pada industri kecil dan menengah berpengaruh secara positif terhadap penyerapan tenaga kerja. Peningkatan tenaga kerja dapat menurunkan jumlah pengangguran dan pada akhirnya meningkatkan pendapatan per kapita suatu daerah. 
Dengan melihat sudah bagusnya dampak DAK Bidang IKM terhadap IPM, maka sebaiknya pola penyaluran dan tata kelola DAK Bidang IKM yang ada saat ini dipertahankan dengan tetap melakukan perbaikan yang diperlukan. Seperti contohnya indikator kinerja belum menggambarkan sejauh mana kualitas dan aksesibilitas dari sentra IKM yang dibangun. Seharusnya indikator kinerja DAK Bidang IKM lebih dapat menggambarkan kinerja dari terbangunnya sebuah sentra IKM seperti tingkat pendapatan IKM di suatu kabupaten/kota, pertumbuhan jumlah IKM, dll. Nilai alokasi DAK bidang IKM yang saat ini merupakan yang terkecil dapat dipertimbangkan untuk dinaikkan agar dapat memacu pembangunan dan kesejahteraan masyarakat di daerah.

\section{Realisasi DAK Bidang Pertanian (DAKPRT) berpengaruh secara positif dan tidak signifikan terhadap indikator kinerja pembangunan}

Hasil penelitian ini tidak sesuai dengan penelitian penelitian Novita, dkk (2009) yang menyebutkan bahwa pengalihan dana investasi ke sektor pertanian dapat memberikan kontribusi besar terhadap penciptaan output, pendapatan dan penyerapan tenaga kerja. Begitu juga penelitian Utomo, dkk (2015) dan Mahali (2015) yang menyebutkan bahwa dampak investasi sektor pertanian secara umum berpengaruh positif terhadap pembentukan output, pembentukan pendapatan, dan terutama dalam penciptaan lapangan pekerjaan, namun hasil penelitian itu menyebutkan juga bahwa perlu adanya peningkatan investasi barang modal yang dapat meningkatkan kualitas dan keterampilan petani. Handayani (2015) yang meneliti efektivitas DAK Pertanian di Kabupaten Sawahlunto juga menemukan bahwa DAK Pertanian kurang efektif karena adanya kebutuhan petani yang sering tidak sesuai dengan petunjuk teknis serta lambatnya penyerapan DAK di awal tahun.

DAK Bidang Pertanian yang dapat memberi pengaruh positif namun tidak signifikan terhadap IPM menunjukkan bahwa perlu adanya penajaman kembali penggunaan dari DAK Bidang Pertanian. Berdasarkan Petunjuk Teknis DAK Bidang Pertanian, indikator kinerja pelaksanaan kegiatan DAK bidang pertanian hanya berupa jumlah terbangunnya balai diklat pertanian dan SMK-Pertanian Pembangunan serta jumlah sumber air yang dibangun. Dari beberapa sasaran kegitan ini, hanya pembangunan sumber air yang bisa memberi dampak langsung terhadap produktivitas pertanian di daerah. Sebaiknya, sasaran penggunaan DAK Bidang Pertanian diperluas ke kegiatan pembangunan infrastruktur dasar seperti pengairan dan mekanisasi pertanian sehingga memberikan dampak yang langsung dapat dirasakan oleh para petani. Pemerintah Pusat sebaiknya juga memberikan keleluasaan kepada daerah agar dapat mengusulkan kegiatan sesuai dengan kebutuhan petani yang ada di daerahnya masingmasing dan tidak terpaku kepada ketentuan yang ada pada petunjuk 
teknis.

Indikator kinerja atas DAK Bidang Pertanian sebaiknya juga diubah tidak lagi hanya melihat berapa jumlah SMK, balai dan sumur air yang dibangun. Indikator kinerja DAK Bidang Pertanian sebaiknya lebih mencerminkan kualitas dan output dari pembangunan yang dilakukan seperti peningkatan keterampilan petani, jumlah lulusan SMK Pertanian, kenaikan produksi pertanian, dan lain-lain. Perubahan ini akan membuat daerah lebih mengoptimalkan efektifitas penggunaan dana dan tidak hanya fokus pada penyerapan anggaran saja.

\section{Realisasi DAK Bidang Kesehatan dan KB (DAKKKB) berpengaruh secara positif dan signifikan terhadap indikator kinerja pembangunan.}

DAK Bidang Kesehatan dan KB memberikan pengaruh yang positif secara signifikan terhadap IPM. Hal ini sesuai dengan penelitian Bappenas (2011, 114) yang juga menunjukkan bahwa terdapat pengaruh yang positif dari DAK Bidang Kesehatan dan KB terhadap IPM secara agregat. Penelitian Bappenas yang menggunakan data periode lebih lama yaitu tahun 2006-2009 menunjukkan bahwa DAK Bidang Kesehatan dan KB secara konsisten memberikan pengaruh positif terhadap IPM sejak dana ini mulai digulirkan oleh pemerintah pusat. Akan tetapi, hasil penelitian ini tidak sesuai dengan penelitian Muliza, dkk (2017) dan Wibowo (2016) yang menemukan bahwa belanja pemerintah di bidang kesehatan tidak memiliki pengaruh signifikan terhadap IPM. Penelitian tersebut juga menunjukkan bahwa pemerintah daerah tidak dapat memanfaatkan belanja kesehatannya dengan efektif.

Bila melihat petunjuk teknis DAK Bidang Kesehatan dan KB, maka arah kebijakan yang ada saat ini sudah tepat yaitu meningkatkan pemerataan pelayanan kesehatan terutama di daerah perbatasan, tertinggal, terpencil dan kepulauan. Hal ini terlihat dari gambar IV.5 yang menunjukkan bahwa nilai rata-rata realisasi DAK Bidang Kesehatan dan KB per kabupaten/kota yang terbesar berada di regional Sulawesi dan Maluku-Papua. Sebaiknya pola alokasi DAK Bidang Kesehatan dan KB ini dipertahankan dengan terus mendorong percepatan penyerapan anggaran oleh pemerintah daerah yang selama ini sering terlambat dan tidak optimal.

Akan tetapi, indikator kinerja atas pelaksanaan kegiatan DAK Bidang Kesehatan dan KB saat ini belum mencerminkan bagaimana tingkat kualitas pelayanan kesehatan yang merupakan sasaran dari disalurkannya DAK Bidang Kesehatan dan KB. Aspek kinerja yang diukur berdasarkan juknis hanyalah realisasi penggunaan keuangan dan realisasi pembangunan/pengadaan fisik kegiatan. Indikator kinerja yang masih sangat berorientasi input ini tentu tidak memacu pemerintah daerah untuk meningkatkan efektifitas dari pembangunan dengan menggunakan DAK 
yang telah diberikan. Fokus pemerintah daerah hanyalah membangun dan meningkatkan penyerapan. Praktik semacam ini rawan dengan penyimpangan dan tidak dapat menciptakan outcome secara optimal. Sebaiknya indikator kinerja DAK Bidang Kesehatan dan KB lebih menggambarkan output yang lebih tepat seperti peningkatan angka harapan hidup, jumlah bayi diimunisasi, presentase masyarakat yang mendapat layanan kesehatan, dan lain-lain.

\section{Realisasi DAK Bidang Kelautan dan Perikanan (DAKKLP) berpengaruh secara negatif dan signifikan terhadap indikator kinerja pembangunan.}

. DAK Bidang Kelautan dan Perikanan memberikan pengaruh yang signifikan namun negatif terhadap IPM. Hal ini menandakan bahwa kebijakan terkait DAK Bidang Kelautan dan Perikanan saat ini belum bisa mencapai tujuan pembangunan. Hasil ini sesuai dengan penelitian Kohar, dkk (2005) yang menghasilkan simpulan bahwa sektor perikanan belum memberikan kontribusi yang besar bagi perekonomian. Pada penelitian tersebut ditemukan juga bahwa sektor perikanan cenderung mendorong sektor hilir dibandingkan dengan sektor hulunya. Hal ini menandakan perlu adanya perhatian dan alokasi pengembangan yang lebih besar pada sektor hulu dari pemerintah. Sebenarnya fokus penggunaan DAK Bidang Kelautan dan Perikanan sudah difokuskan pada sektor hulu di mana sasarannya adalah untuk pembangunan Tempat Pelelangan Ikan (TPI), sarana prasarana perbenihan dan sarana pemberdayaan usaha skala kecil masyarakat. Bila kita melihat pengaruhnya yang belum positif, maka perlu dicek kembali apakah memang penggunaan DAK Bidang Kelautan dan Perikanan sudah sesuai dengan ketentuan yang telah ditetapkan.

Berdasarkan identifikasi permasalahan di bidang kelautan dan perikanan yang susun oleh Kamar Dagang dan Industri (Kadin) Indonesia pada tahun 2014, peta permasalahan dalam bidang kelautan dan perikanan di Indonesia antara lain adalah belum optimalnya produksi perikanan budidaya nasional dan produksi perikanan tangkap, belum terkelolanya pulau-pulau kecil sebagai kekuatan ekonomi, belum optimalnya industri pengolahan perikanan (khususnya di kawasan Indonesia Bagian Timur), belum cukupnya ketersediaan BBM untuk nelayan dan pembudidayaan ikan, dan masih rendahnya kapasitas SDM kelautan dan perikanan. Seharusnya penggunaan DAK bidang kelautan dan perikanan dapat difokuskan pada permasalahan tersebut.

Dengan melihat bahwa pengaruhnya yang negatif terhadap IPM, maka sebaiknya perlu dilakukan perbaikan kebijakan DAK Bidang Kelautan dan Perikanan yang ada saat ini. Dari sisi perencanaan, perlu didiskusikan penggunaan yang lebih efektif untuk mengembangkan sektor perikanan dalam rangka menstimulus perekonomian. Pada level pelaksanaan, perlu diidentifikasi kendala apa saja yang terjadi di daerah terkait dengan 
pelaksanaan DAK Bidang Kelautan dan Perikanan. Sedangkan pada level monitoring dan evaluasi, perlu dilakukan pengujian apakah DAK Bidang Kelautan dan Perikanan telah digunakan sesuai dengan peruntukannya.

Indikator kinerja DAK Bidang Kelautan dan Perikanan saat ini sebenarnya sudah cukup bagus dengan mencantumkan indikator output/ outcome yang sesuai dengan tujuan DAK Bidang Kelautan dan Perikanan antara lain produksi perikanan, produksi garam, dan pendapatan per orang. Akan tetapi yang perlu mendapat perhatian adalah yang selama ini digunakan sebagai indikator kinerja hanyalah capaian output berupa jumlah sarana prasarana yang telah terbangun atau dihasilkan dari realisasi DAK dan belum mencakup seberapa besar outcome yang dihasilkan. Hal ini membuat pemerintah daerah hanya berfokus untuk mencapai output berupa jumlah sarana yang terbangun tersebut tanpa memikirkan apakah sarana tadi telah memberikan manfaat yang sebesar-besarnya pada sektor kelautan dan perikanan daerah.

\section{Realisasi DAK Bidang Pendidikan (DAKPDK) berpengaruh secara negatif dan signifikan terhadap indikator kinerja pembangunan.}

DAK Bidang Pendidikan memberikan pengaruh signifikan negatif tidak sesuai dengan penelitian Bappenas (2011) yang menunjukkan bahwa DAK Bidang Pendidikan tidak berpengaruh terhadap IPM dan dan Muliza, dkk (2011) yang menyebutkan bahwa belanja pemerintah di bidang pendidikan juga tidak berpengaruh terhadap IPM. Hasil pengujian yang memberikan pengaruh signifikan negatif mungkin dikarenakan penurunan nilai realisai DAK Bidang Pendidikan yang cukup drastis di tahun 2015 s.d. 2018. Hal ini sejalan dengan penelitian Juanda dan Handra $(2017,11)$ yang menyatakan bahwa semakin kecil nilai DAK maka juga akan memperkecil pengaruhnya terhadap pencapaian prioritas nasional.

Juknis pelaksanaan DAK Bidang Pendidikan juga tidak menyebutkan indikator kinerja berupa output/outcome yang jelas dan rinci. Disebutkan bahwa indikator kinerja DAK Bidang Pendidikan hanyalah kesesuaian dokumen, kelengkapan dokumen, kesesuaian hasil pelaksanaan, dan kepatuhan dan ketertiban laporan

Nilai realisasi DAK Bidang Pendidikan yang cenderung menurun dalam 3 tahun terakhir juga menimbulkan pertanyaan apakah saat ini infrastruktur pendidikan di Indonesia sudah cukup memadai. Dengan nilai realisasi DAK Bidang Pendidikan yang menurun, daerah menjadi lebih bergantung pada jenis pendapatan lain seperi PAD, DBH dan DAU yang saat ini belum bisa diandalkan mengingat ruang fiskal pemerintah daerah yang terbatas dengan kebutuhan pembayaran gaji pegawai dan belanja yang sangat besar (Wardhana, dkk, 2013, 114).

seharusnya terdapat perbaikan kebijakan tata kelola DAK Pendidikan 
agar dapat memberikan manfaat yang lebih optimal kepada pembangunan manusia di daerah. Dari segi nilai alokasi, seharusnya dengan melihat masih kurangnya infrastruktur pendidikan di Indonesia, pemerintah pusat dapat mempertimbangkan untuk menaikkan nilai alokasi DAK Bidang Pendidikan. Dari segi penilaian kinerja, pemerintah pusat dapat menyusun indikator kinerja yang lebih memacu pemerintah daerah untuk meningkatkan efektivitas DAK Bidang Pendidikan yang mereka terima. Hal yang bisa dilakukan adalah dengan membuat indikator kinerja berbasis output yang dapat menggambarkan kualitas dan aksesibilitas dari layanan pendidikan seperti tingkat partisipasi sekolah, tingkat harapan lama sekolah, presentase lulusan yang melanjutkan ke sekolah menengah tinggi, dan lain-lain.

Selain itu, dengan melihat bahwa dampak positif dari pembangunan sarana dan prasarana sekolah baru akan terlihat dalam waktu yang lama, maka pemerintah sebaiknya melakukan evaluasi dalam jangka menengah atau panjang terkait efektivitas realisasi DAK Pendidikan dalam meningkatkan kualitas dan akses pendidikan masyakarat di daerah. Evaluasi ini dapat dilakukan terpisah dari kegiatan monitoring tahunan yang dilakukan secara rutin, dimana hasilnya digunakan untuk merumuskan perbaikan kebijakan DAK Pendidikan dalam jangka panjang.

\section{Realisasi DAK Bidang Perumahan Pemukiman, Air Minum dan Sanitasi (DAKPMS) berpengaruh secara negatif dan signifikan terhadap indikator kinerja pembangunan.}

DAK Bidang Perumahan, Air Minum, dan Sanitasi memberikan pengaruh yang signifikan dan negatif terhadap IPM. Hasil ini tidak sesuai dengan penelitian Mahulauw, dkk (2010) yang menyatakan bahwa pengeluaran di bidang infrastruktur berpengaruh signifikan terhadap IPM. Kustanto (2015) juga menemukan bahwa pembangunan akses air dan sanitasi seharusnya akan berpengaruh terhadap derajat kesehatan. Semakin tinggi derajat kesehatan maka akan meningkatkan angka harapan hidup dan kesejahteraan masyarakat secara umum. Mengingat Angka harapan hidup merupakan salah satu komponen IPM, maka seharusnya pembangunan akses air dan sanitasi berpengaruh terhadap angka IPM secara keseluruhan.

Hasil pengujian yang bernilai negatif dapat dikarenakan DAK Bidang Perumahan, Air Minum, dan Sanitasi memiliki tren rata-rata realisasi yang hampir sama dengan DAK Bidang Pendidikan yaitu terdapat penurunan nilai realisasi yang cukup besar di tahun 2016 walaupun sempat meningkat kembali di tahun 2017. Penurunan nilai realisasi DAK Bidang Perumahan, Air Minum, dan Sanitasi pada tahun 2017 tidak sejalan dengan tren alokasi DAK secara umum yang sebenarnya naik cukup tinggi di tahun 2017 seperti yang dijelaskan di gambaran umum. Hal ini menandakan bahwa DAK Bidang Perumahan, Air Minum, dan Sanitasi tidak menjadi fokus/prioritas pemerintah di tahun 2017. 
Lebih lanjut lagi, DAK Bidang Perumahan, Air Minum, dan Sanitasi sejak tahun 2017 dipecah menjadi 3 bidang DAK tersendiri yaitu DAK Bidang Perumahan, DAK Bidang Air Minum, dan DAK Bidang Sanitasi. Pemecahan ini dilakukan oleh pemerintah dalam rangka melaksanakan kebijakan penajaman bidang di DAK (Juanda dan Handra, 2017, 11). Pemecahan ini diharapkan dapat membuat pelaksanaan DAK menjadi lebih terfokus dan optimal. Hal ini diduga membuat dampak dari DAK memang belum terlihat pada analisis penelitian ini karena pada tahun 2016 dan 2017 DAK Bidang Perumahan, Air Minum, dan Sanitasi masih digabung menjadi 1 (satu) bidang saja. Diharapkan setelah dilaksanakan selama beberapa tahun dari sekarang, penelitian selanjutnya dapat menganalisis apakah penajaman bidang tersebut dapat meningkatkan dampak yang diberikan oleh DAK Bidang Perumahan, Air Minum, dan Sanitasi.

Untuk ke depannya, dengan mengingat belum positif dan signifikannya pengaruh DAK Bidang Perumahan, Air Minum, dan Sanitasi terhadap IPM, maka sebaiknya pemerintah tetap melanjutkan kebijakan penajaman DAK yang sudah dilaksanakan sejak tahun 2017. Akan tetapi, penajaman tersebut harus disertai dengan pemantauan dan evaluasi yang memadai. Saat ini indikator kinerja DAK Bidang Perumahan, Air Minum, dan Sanitasi juga masih sama seperti DAK bidang lainnya yaitu berupa output satuan hasil pembangunan dan belum mencakup output manfaat dari pembangunan tersebut. Sebaiknya indikator kinerja DAK PMS lebih ditekankan pada output yang menggambarkan kualitas hidup masyarakat seperti presentase masyakarat tinggal di perumahan kumuh, presentase akses masyarakat terhadap air minum layak dan presentase masyarakat dengan akses sanitasi memadai.

\section{Realisasi DAK Bidang Transportasi (DAKTRP) berpengaruh secara positif dan signifikan terhadap indikator kinerja pembangunan.}

DAK Bidang Transportasi memiliki pengaruh yang signifikan dan positif terhadap IPM. Hasil penelitian ini sejalan dengan penelitian Pinkan (2016) yang menyebutkan bahwa pengeluaran pemerintah di bidang transportasi dapat meningkatkan perekonomian dalam jangka panjang. Peningkatan perekonomian selanjutnya juga akan meningkatkan tingkat pembangunan manusia di suatu wilayah. Peningkatan pembangunan manusia di suatu wilayah terkait dengan akses manusia dan barang yang semakin mudah sehingga menstimulus perekonomian menjadi lebih efisien dan ekonomis. Peningkatan akses transportasi secara tidak langsung juga akan meningkatkan taraf kesehatan dan pendidikan masyarakat karena lebih memudahkan mereka dalam mencapai fasilitas kesehatan maupun pendidikan.

Dengan melihat pengaruhnya yang positif dan signifikan, pemerintah seharusnya tetap menjaga atau meningkatkan alokasi DAK 
Bidang Transportasi. Mengingat efek dari transportasi baru dapat dirasakan dalam jangka panjang, pemerintah juga dapat melakukan evaluasi jangka menengah dalam beberapa tahun untuk menentukan apakah prioritas dan penggunaan DAK Bidang Transportasi saat ini sudah tepat. Penilaian kinerja DAK Bidang Transportasi seharusnya juga diwujudkan dalam manfaat yang bisa diukur dari meningkatnya akses transportasi masyarakat seperti indeks kemahalan, presentase jalan berstatus mantap, dan lain-lain.

9. Pengaruh Produk Domestik Regional Bruto, Pertumbuhan Ekonomi, Opini Laporan Keuangan, Jenis Pemerintah Daerah dan Lokasi Daerah terhadap Indikator Kinerja Pembangunan

a. Produk Domestik Regional Bruto (PDRB) Berpengaruh Secara Positif dan Signifikan terhadap Indikator Kinerja Pembangunan.

Variabel PDRB yang berpengaruh secara positif dan signifikan terhadap IPM sesuai dengan penelitian Hasan (2016) dan Prayogo (2017) yang menyebutkan bahwa produk domestik bruto suatu daerah berpengaruh terhadap IPM daerah tersebut. Hal ini menunjukkan bahwa peningkatan kualitas hidup masyarakat berbanding lurus dengan tingkat perekonomiannya.

Tabel 7. Rata-Rata IPM Daerah berdasarkan Kelompok PDRB

\begin{tabular}{cc}
\hline Kelompok PDRB & Rata-Rata IPM \\
\hline $0-100$ triliun & 67,37402 \\
\hline $100-200$ triliun & 75,70179 \\
\hline $200-300$ triliun & 71,88408 \\
\hline $300-400$ triliun & 80,30684 \\
\hline All & 67,53404 \\
\hline
\end{tabular}

Sumber: hasil olah data

Lebih lanjut pada Tabel 7. dapat kita lihat bahwa daerah dengan tingkat PDRB tinggi memiliki rata-rata IPM yang tinggi, sedangkan daerah dengan PDRB rendah memiliki tingkat IPM yang relatif lebih rendah pula. Sebaran data tersebut mengindikasikan bahwa pemerintah pusat dan daerah harus mengambil kebijakan untuk menstimulus perekonomian agar kualitas hidup masyarakatnya juga meningkat.

b. Pertumbuhan Ekonomi Tidak Berpengaruh Signifikan terhadap Indikator Kinerja Pembangunan

Variebel pertumbuhan ekonomi tidak berpengaruh terhadap IPM kabupaten/kota yang mana hasil estimasi menunjukkan koefisien senilai 0,000156 dan probabilitas sebesar 0,9818. Hasil penelitian ini tidak sesuai dengan UNDP (1996) yang menyatakan bahwa pertumbuhan ekonomi menyediakan sumber daya untuk perbaikan pengembangan manusia. Namun hal ini dapat menjelaskan temuan Ranis $(2004,8)$ yang menjelaskan bahwa keterkaitan antara pertumbuhan ekonomi dan IPM 
akan melemah jika dipengaruhi oleh adanya korupsi pemerintah, pengeluaran sosial yang rendah atau pendistribusian pendapatan yang tidak seimban. Maka peningkatan akses masyarakat terhadap hasil pembangunan dapat ditingkatkan melalui perbaikan kapabilitas lembaga pemerintah daerah, pemberantasan korupsi pemerintah, peningkatan pengeluaran sosial dan pendistribusian pendapatan kepada masyarakat berkategori pendapatan rendah.

Tabel 8. Rata-Rata Pertumbuhan Ekonomi Daerah berdasarkan Rentang IPM

\begin{tabular}{cc}
\hline Rentang IPM & Rata-Rata Pertumbuhan Ekonomi (\%) \\
\hline $20-40$ & 7,702 \\
\hline $40-60$ & 5,694 \\
$60-80$ & 5,500 \\
\hline $80-100$ & 5,949 \\
All & 5,533 \\
\hline
\end{tabular}

Sumber: hasil olah data

c. Opini Laporan Keuangan Daerah Berpengaruh Secara Positif dan Signifikan terhadap Indikator Kinerja Pembangunan.

Jika opini laporan keuangan pemerintah daerah dikategorikan baik, maka terdapat perbedaan IPM sebesar 2,19 dibanding daerah dengan opini laporan keuangan yang buruk. Hal ini menunjukkan bahwa kapabilitas instansi pemerintah daerah dalam menjalankan manajemen keuangannya cukup menentukan tingkat pengembangunan manusia di daerah tersebut.Hasil penelitian ini sejalan dengan penelitian Lewis (2018, 12) yang menunjukkan bahwa daerah dengan hasil audit laporan keuangan yang baik memiliki tingkat delivery service yang lebih baik pula. Audit yang dilakukan kepada pemerintah daerah secara umum menggambarkan kinerja manajemen keuangan dan mengindikasikan apakah terdapat keborosan, penyalahgunaan sumber daya dan fraud dalam pengelolaan pemerintahan. Pemerintah daerah harus meningkatkan tingkat kapabilitas instansinya dalam menjalankan manajemen keuangan sehingga dapat menghasilkan barang pubik dengan lebih efisien. Pengelolaan barang publik yang lebih efisien akan memberikan dampak yang lebih baik terhadap perekonomian dan pembangunan manusia.

Pada Gambar 4, kita dapat melihat bahwa daerah dengan opini laporan keuangan baik rata-rata memiliki tingkat kemandirian daerah sebesar 15,82\%, cukup jauh bila dibandingkan dengan daerah yang memiliki opini laporan keuangan buruk yang mana hanya mencapai $5,87 \%$. Tingkat kemandirian daerah adalah variabel yang menunjukkan rasio antara pendapatan asli daerah dengan dana perimbangan yang diterima daerah dari pemerintah pusat. Lebih tingginya rasio kemandirian daerah pada daerah dengan opini laporan keuangan yang baik menunjukkan bahwa peningkatan kualitas manajemen keuangan suatu 
daerah akan selaras dengan jumlah PAD yang bisa dihimpun.

Gambar 4. Perbandingan Kemandirian Fiskal Daerah antara Daerah dengan Opini Laporan Keuangan Baik dan Buruk

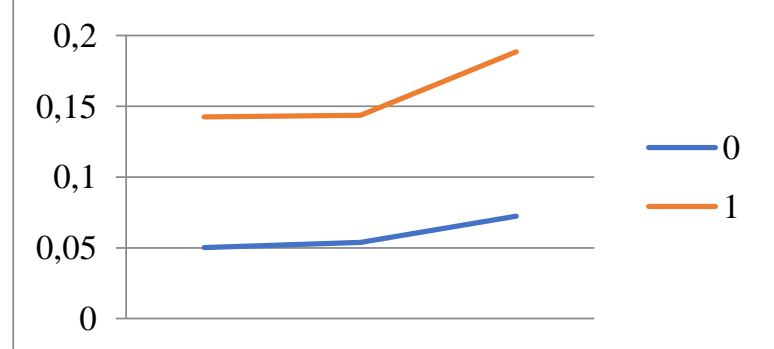

Sumber: diolah dari DJPK Kemenkeu dan BPK

Hal yang sama juga terlihat pada perbandingan derajat desentralisasi seperti yang ditampilkan pada Gambar 5 Daerah dengan opini laporan keuangan baik memiliki rata-rata derajat desentralisasi sebesar $11,32 \%$, sedangkan daerah dengan opini laporan keuangan buruk hanya memiliki rata-rata derajat desentralisasi sebesar 5,07\%. Derajat desentralisasi menunjukkan rasio PAD terhadap total belanja daerah. Derajat desentralisasi yang lebih baik pada daerah dengan opini laporan keuangan baik memiliki interpretasi yang sama dengan perbandingan kemandirian daerah yang telah dijelaskan sebelumnya, dimana sangat terkait dengan kemampuan daerah dalam mengembangkan pendapatan asli daerahnya.

Gambar 5. Perbandingan Derajat Desentralisasi antara Daerah dengan Opini Laporan Keuangan Baik dan Buruk

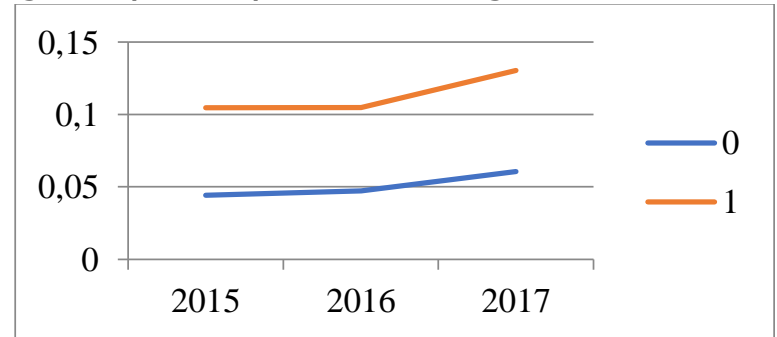

Sumber: diolah dari DJPK Kemenkeu dan BPK

d. Jenis Pemerintahan Daerah Berpengaruh Secara Positif dan Signifikan terhadap Indikator Kinerja Pembangunan.

Variabel dummy jenis pemerintahan daerah yang berpengaruh secara positif dan signifikan bahkan dengan koefisien yang cukup tinggi menunjukkan bahwa daerah dengan jenis pemerintahan kabupaten masih harus terus mengejar ketertinggalannya dengan daerah yang berjenis pemerintahan kota. Kondisi ini bisa dijelaskan dari masih cukup tingginya perbedaan rata-rata IPM dalam kurun waktu tahun 2016 s.d. 2018 antara daerah berjenis pemerintahan kota dengan daerah berjenis pemerintahan kabupaten. 
Gambar 6. Perbandingan Rata-Rata IPM Daerah Berjenis Pemerintahan Kota dan Kabupaten

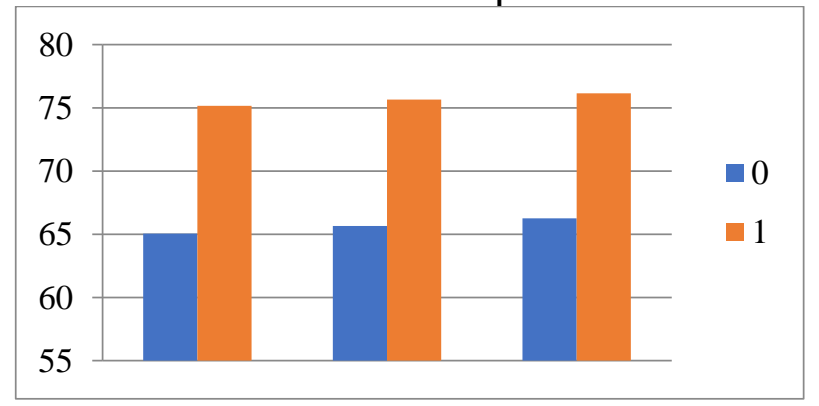

Sumber: diolah dari https://ipm.bps.go.id/

Salah satu implikasi kebijakan yang bisa diambil adalah dengan memberikan prioritas terhadap daerah berjenis kabupaten terutama kabupaten yang termasuk ke dalam status daerah tertinggal. Adapun kebijakan tersebut sudah dijalankan oleh pemerintah saat ini dengan dibuatnya jenis DAK Afirmasi, yaitu DAK yang diperuntukkan khusus bagi daerah di wilayah perbatasan, tertinggal, dan/atau kepulauan.

e. Lokasi Daerah (Jawa/Luar Jawa) Berpengaruh Secara Positif dan Signifikan terhadap Indikator Kinerja Pembangunan.

Variabel dummy lokasi daerah yang berpengaruh secara positif terhadap IPM menunjukkan bahwa masih terdapat ketimpangan IPM antara daerah yang ada di Pulau Jawa dengan di luar Pulau Jawa. Ketimpangan tersebut bisa dijelaskan salah satunya melalui data bahwa pembentukan total produk domestik bruto Indonesia 50\%-nya masih dihasilkan di daerah Jawa, sedangkan sisanya secara berturut-turut dari yang paling besar dihasilkan di wilayah Sumatera, Kalimantan, Sulawesi, Nusa Tenggara dan Maluku-Papua.

Gambar 7. Proporsi PDRB Regional atas PDRB Indonesia Secara Total

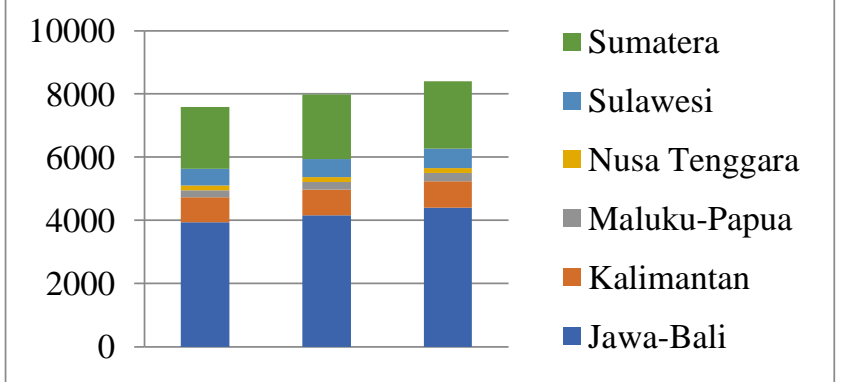

Sumber: diolah dari Katalog PDRB Kabupaten/Kota Indonesia (BPS)

Hasil penelitian ini mendukung sasaran pemerintah yang terus mengupayakan pembangunan dari daerah pinggiran atau daerah tertinggal sehingga perekonomian dapat berkembang secara merata. Implikasi kebijakannya bisa dengan meningkatkan alokasi untuk daerah tertinggal dan menjadikan daerah tertinggal sebagai prioritas penerima DAK. 


\section{SIMPULAN}

Berdasarkan penelitian yang telah dilakukan atas pengaruh DAK per bidang terhadap indikator kinerja pembangunan berupa Indeks Pembangunan Manusia (IPM); DAK Bidang Industri Kecil Menengah berpengaruh secara positif dan signifikan terhadap indikator kinerja pembangunan. DAK Bidang Pertanian berpengaruh secara positif namun tidak signifikan terhadap indikator kinerja pembangunan. DAK Bidang Kesehatan dan KB berpengaruh secara positif dan signifikan terhadap indikator kinerja pembangunan. DAK Bidang Kelautan dan Perikanan berpengaruh secara negatif dan signifikan terhadap indikator kinerja pembangunan. DAK Bidang Pendidikan berpengaruh secara negatif dan signifikan terhadap indikator kinerja pembangunan. DAK Bidang Perumahan, Air Minum dan Sanitasi berpengaruh secara negatif dan signifikan terhadap indikator kinerja pembangunan. DAK Bidang Transportasi berpengaruh secara positif dan signifikan terhadap indikator kinerja pembangunan. Produk domestik regional bruto, opini laporan keuangan daerah, jenis pemerintah daerah dan lokasi daerah berpengaruh terhadap indikator kinerja pembangunan secara positif dan signifikan, sedangkan pertumbuhan ekonomi tidak berpengaruh.

\section{Kontribusi dan Keterbatasan Penelitian}

Karena ada keterkaitan positif antara DAK sesuai bidangnya dengan indek pembangunan manusia, maka alokasi anggaran DAK sebaiknya lebih ditingkatkan untuk tahun-tahun berikutnya. Mengubah Fokus Penggunaan DAK Bidang Pertanian ke Infrastruktur Dasar dan Pemberian Keleluasaan Penggunaan Dana yang Lebih kepada Daerah, Menjaga dan Mengevaluasi Outcome DAK Bidang Kesehatan secara Berkala serta Mendorong Percepatan Penyerapan Anggaran

Proses penelitian memiliki keterbatasan-keterbatasan dalam hal Rentang waktu yang digunakan sebagai data penelitian hanya selama 3 tahun dan Bidang DAK yang diteliti baru terbatas pada DAK yang telah konsisten disalurkan selama 3 tahun masa penelitian.

\section{DAFTAR PUSTAKA}

Broadway, Robin dan Shah, Anwar. 2007. Intergovernmental Fiscal Transfers Principle and Practice. Public Sector Governance and Accountability Series. New York.

Bappenas. 2011. Analisis Perspektif, Permasalahan dan Dampak Dana Alokasi Khusus (DAK). Jakarta.

Dillinger, William. 1994. Decentralization and Its Implications For Urban Service Delivery. Urban Management Programme.

Fadhly, Zul. 2016. Pengaruh Pendapatan Asli Daerah, Dana Alokasi Umum dan Dana Alokasi Khusus terhadap Indeks Pembangunan Manusia di Provinsi Sumatera Barat. Padang: Univ. Negeri Padang.

Hadiyanti, Sofia. 2015. Pengaruh Investasi pada Industri Kecil dan Industri 
Menengah terhadap Penyerapan Tenaga Kerja di Kota Samarinda. Jurnal IImu Ekonomi dan Pembangunan UNS.

Hasan, Nurhikmah Amalia. 2016. Pengaruh Produk Domestik Regional Bruto (PDRB), Kemiskinan dan Belanja Modal terhadap Indeks Pembangunan Manusia (IPM) di Daerah Istimewa Yogyakarta. Yogyakarta: Universitas Muhammadiyah Yogyakarta.

Juanda, Bambang, and Hefrizal Handra. 2017. "Reformasi Mekanisme Dana Alokasi Khusus (DAK) Untuk Mendorong Pertumbuhan Dan Pemerataan Pembangunan Di Indonesia." Kompak (2).

Kohar, dkk. 2006. Dampak Investasi Sektor Perikanan terhadap Perekonomian Jawa Tengah. Semarang: Universitas Diponegoro.

Kustanto, Deka Nata. 2015. Dampak Akses Air Minum dan Sanitasi terhadap Peningkatan Kesejahteraan. Jurnal Sosial Ekonomi Pekerjaan Umum.

Lewis, Blane D. 2016. Local Government Spending and Service Delivery in Indonesia: The Perverse Effects Of Substantial Fiscal Resources Regional Studies.

Lusiana Sari, Handayani. 2015. Analisis Efektifitas Dana Alokasi Khusus (DAK) Bidang Pertanian di Kota Sawahlunto. Padang: Universitas Andalas.

Mahulauw, Santosa dan Mahardika. 2016. Pengaruh Pengeluaran Kesehatan dan Pendidikan serta Infrastruktur terhadap Indeks Pembangunan Manusia di Provinsi Maluku. Jurnal Ekonomi Pembangunan Universitas Brawijaya.

Martinez, Jorge dan Vazquez. 2011. The Impact of Fiscal Decentralization: Issues in Theory and Challenges in Practice. Georgia: Georgia State University Economics Faculty Publication.

Martinez-Vazquez, Jorge, and Robert Martin McNab. 2005. "Fiscal Decentralization and Economic Growth." SSRN Electronic Journal (January). doi: 10.2139/ssrn.259281.

Melliana, A. 2013. Analisis Statistika Faktor yang Mempengaruhi Indeks Pembangunan Manusia di Kabupaten/Kota Provinsi Jawa Timur. Surabaya: Institut Sepuluh November.

Mihaela dan Georgiana. 2015. Correlations Between Human Development and Economic Growth. Romania.

Muliza, Zulham dan Seftarita. 2017. Analisis Pengaruh Belanja Pendidikan, Belanja Kesehatan, Tingkat Kemiskinan dan PDRB terhadap IPM di Provinsi Aceh. Jurnal Perspektif Ekonomi Darussalam.

Novita, Rahmanta dan Mahalli. 2008. Dampak Investasi Sektor Pertanian terhadap Perekonomian Sumatera Utara. Medan: Universitas Sumatera Utara.

Pasaribu, B. F. Rowland. 2005. "Indikator Pembangunan." Teori Pembangunan (Alexander 1994):16-28. doi: 10.1016/j.jiheatmasstransfer.2018.07.009 
Petchey, Jeffrey dan Macdonald, Garry. 2007. Financing Capital Expenditures through Grants. Public Sector Governance and Accountability Series. New York.

Oates, W.E. 1999. An Essay on Fiscal Federalism. Journal of Economic Literature

Pasaribu, Rowland Bismark Fernando. 2012. Bahan Ajar Ekonomi Pembangunan. Fakultas Ekonomi. Depok: Universitas Gunadarma.

Pinkan, Nadia. 2016. Pengaruh Belanja Pemerintah di Bidang Transportasi terhadap Perekonomian Nasional. Yogyakarta: Universitas Gajah Mada.

Prayogo, Pungki Ardi. 2017. Analisis Pengaruh PDRB, Upah Minimum, Jumlah Pengangguran dan Kemiskinan terhadap Indeks Pembangunan Manusia di Kabupaten/Kota Provinsi Jawa Timur. Malang: Universitas Muhammadiyah Malang.

Purba, Sri Purnamawaty. 2016. Pengaruh Pendapatan Asli Daerah, Dana Alokasi Umum, Dana Alokasi Khusus terhadap Indeks Pembangunan Manusia melalui Belanja Modal dan Pertumbuhan Ekonomi pada Kabupaten/Kota di Propinsi Sumatera Utara. Tesis Univ. Sumatera Utara.

Ranis, Gustav. 2004. Human Development and Economic Growth. Yale University.

Saputra dan Mahmudi. 2011. Pengaruh Desentralisasi Fiskal terhadap Pertumbuhan Ekonomi dan Kesejahteraan Masyarakat. Jurnal Akuntansi dan Auditing Indonesia.

Siswiyanti, Pungky. 2015. Pengaruh PAD, DAU, DAK terhadap Pertumbuhan Ekonomi dengan Belanja Modal sebagai Variabel Intervening. Jurnal Akuntansi Univ. Negeri Surabaya.

Sidik, Machfud. 2002. "Perimbangan Keuangan Pusat Dan Daerah Sebagai Pelaksanaan Desentralisasi Fiskal (Antara Teori Dan Aplikasinya Di Indonesia)." Setahun Implementasi Kebijaksanaan Otonomi Daerah Di Indonesia.

Sulaeman, Agus Sunarya, and Vivin Silvia. 2019. "Pendapatan Asli Daerah,Transfer Daerah, Dan Belanja Modal, Pengaruhnya Terhadap Pertumbuhan Ekonomi Regional Di Indonesia." Jurnal Aplikasi Akuntansi. doi: 10.29303/jaa.v4i1.61.

Sulaeman, Agus Sunaryo. 2018. "Probability Financial Distress Pada Pemerintah Daerah Kabupaten Dan Kota Di Indonesia; Analisis Terhadap Faktor Keuangan Dan Dampak Pemekaran Wilayah." Simposium Nasional Akuntansi XXI, Samarinda, 2018 1-24.

Suwandi, and Ari Warokka. 2013. "Fiscal Decentralization and Special Local Autonomy: Evidence from an Emerging Market." The Journal of Southeast Asian Research 2013:1-14. doi: 10.5171/2013.554057.

Taiwo, Falohun dan Agwu. 2016. SMEs Financing and Its Effects on Nigerian Economic Growth. European Journal of Business, Economics 
and Accountancy.

Tikson, Deddy. 2005. Keterbelakangan dan Ketergantungan, Teori Pembangunan di Indonesia, Malaysiah dan Thailand. Makassar: Ininnawa.

United Nations Development Programme. 2016. Human Development Report 2016: Human Development for Everyone.

UNDP. 2016. Human Development Report 2016. New York.

Utomo, Badjuri dan Hadi. 2015. Dampak Investasi Sektor Pertanian terhadap Perekonomian Provinsi Jawa Timur. Artikel Ilmiah Mahasiswa Universitas Jember

Wardhana, Adhitya, Bambang Juanda, Hermanto Siregar, and Kodrat Wibowo. 2013. "Dampak Transfer Pemerintah Pusat Terhadap Penurunan Ketimpangan Pendapatan Di Indonesia." Sosiohumaniora 15(2):111. doi: 10.24198/sosiohumaniora.v15i2.5737.

Wibowo, Sigit. 2016. Analisis Pengaruh Pengeluaran Pemerintah Sektor Pendidikan dan Sektor Kesehatan terhadap IPM dan Pertumbuhan Ekonomi. Jakarta: Program Pascasarjana Universitas Terbuka.

Zul Fadhly. 2013. "Pengaruh Pendapatan Asli Daerah, Dana Alokasi Umum Dan Dana Alokasi Khusus Terhadap Indeks Pembangunan Manusia Di Provinsi Sumatera Barat." Pengaruh Pendapatan Asli Daerah, Dana Alokasi Umum Dan Dana Alokasi Khusus Terhadap Indeks Pembangunan Manusia Di Provinsi Sumatera Barat 1(1):1-15. 